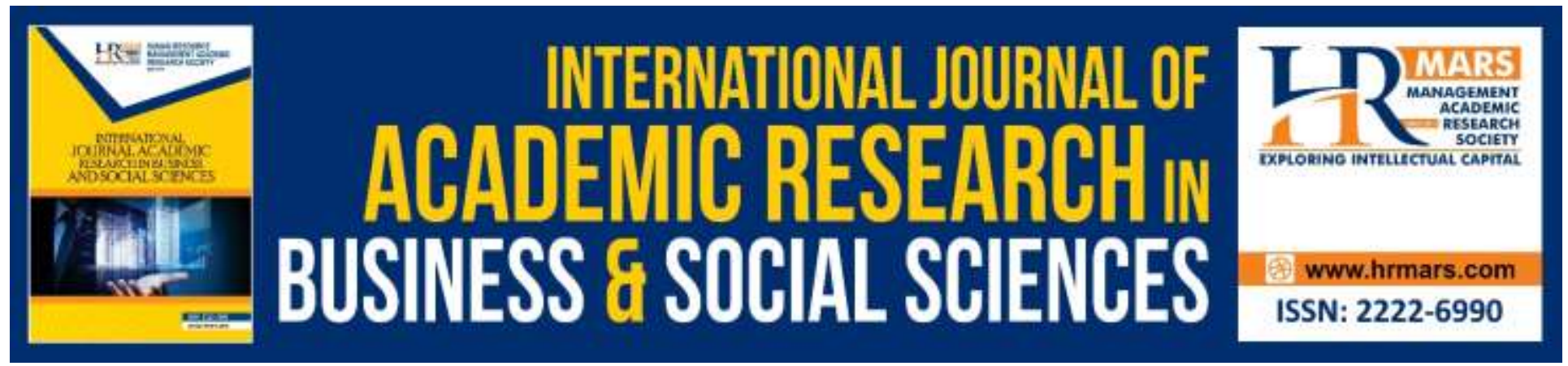

\title{
Influence of Adverse Selection due to Asymmetric Information on Commercial Banks' Lending Performance in Rwanda
}

Mukasafari Chantal, G. S. Namusonge, Dr Jaya Shukla

To Link this Article: http://dx.doi.org/10.6007/IJARBSS/v9-i11/6641

DOI: 10.6007/IJARBSS/v9-i11/6641

Received: 10 October 2019, Revised: 27 October 2019, Accepted: 03 November 2019

Published Online: 30 November 2019

In-Text Citation: (Chantal, Namusonge, \& Shukla, 2019)

To Cite this Article: Chantal, M., Namusonge, G. S., \& Shukla, J. (2019). Influence of Adverse Selection due to Asymmetric Information on Commercial Banks' Lending Performance in Rwanda. International Journal of Academic Research in Business and Social Sciences, 9(11), 1105-1127.

Copyright: (C) 2019 The Author(s)

Published by Human Resource Management Academic Research Society (www.hrmars.com)

This article is published under the Creative Commons Attribution (CC BY 4.0) license. Anyone may reproduce, distribute, translate and create derivative works of this article (for both commercial and non-commercial purposes), subject to full attribution to the original publication and authors. The full terms of this license may be seen at: http://creativecommons.org/licences/by/4.0/legalcode

Vol. 9, No. 11, 2019, Pg. 1105 - 1127

http://hrmars.com/index.php/pages/detail/IJARBSS

JOURNAL HOMEPAGE

Full Terms \& Conditions of access and use can be found at http://hrmars.com/index.php/pages/detail/publication-ethics 


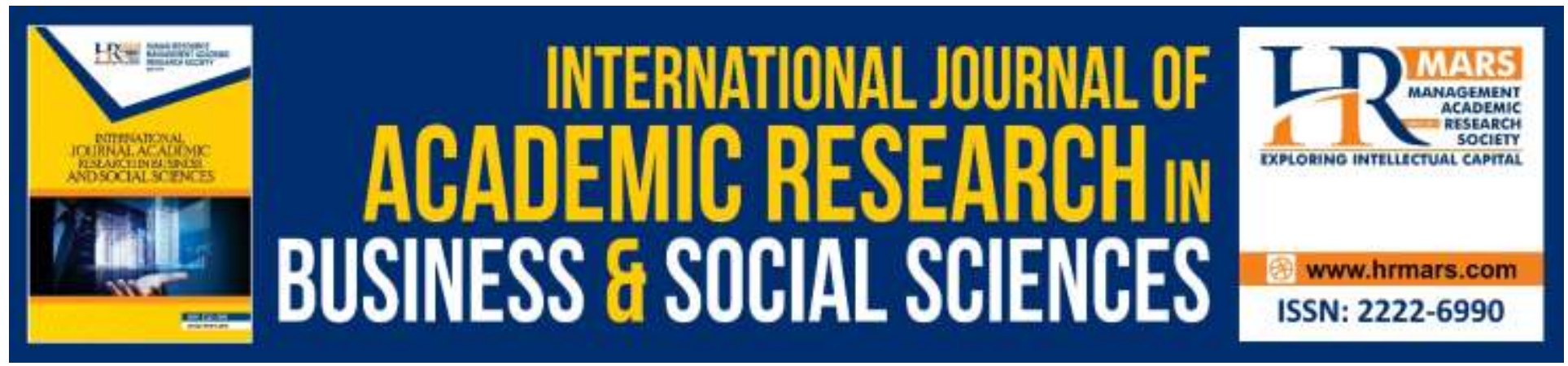

\title{
Influence of Adverse Selection due to Asymmetric Information on Commercial Banks' Lending Performance in Rwanda
}

\author{
Mukasafari Chantal \\ PHD candidate, Department of Economics, Accounting and Finance in the School of Business, in \\ partial fulfillment for the award of the degree of Doctor of Philosophy in Business \\ Administration of the Jomo Kenyatta University of Agriculture and Technology. \\ Prof. G. S. Namusonge, Dr. Jaya Shukla \\ Jomo Kenyatta University of Agriculture and Technology/ Nairobi-Kenya. \\ Email: gsnamusonge@gmail.com, js.jayashukla@gmail.com
}

\begin{abstract}
This study about the influence of adverse selection asymmetric information to the commercial banks' lending in Rwanda means that there a requirement of reducing information asymmetry in order to allow the performance lending in commercial banks of Rwanda.

The study followed both correlation and comparative designs, and used both qualitative and quantitative. The population under study was comprised of board of directors, executives, top managers, middle managers and lower managers of 10 strong markets leadership in banking sector in Rwanda. The researcher used systematic random sampling method in each strata to select 278 from 931 people. The researcher used both primary and secondary source of data. Discriminating variables of ratios were analyzed using the Altman ' $Z$ " score. The data were analyzed using Statistical Packaging for Social Sciences (SPSS) and E-Xcel. In relation to the research objective, the study found that the coefficient $r$ equal to 0.986 . This leads to confirm that there is significant positive relationship between adverse selection asymmetric information and performance of bank.
\end{abstract}

Keywords: Adverse Selection, Information Asymmetry, Banks Lending.

\section{Introduction}

Adverse selectio affects companies' business transactions, whereby company needs to undergo significant structural transformation to be able to become the main driver of economic growth 
due to the market microstructure information (Frank, 2000). Worldwide, the usage of adverse selection has been a tremendous growth in manufacturng industries in the recent past. The most obvious example is perhaps the companies, where through the introduction of information technology related products in transaction, electronic payments, security investmentsand information exchange, companies now provide more diverse services to customers with less manpower (Gautam \& Riitta, 2001).

Adverse selection is confronted with problem of alternative decision making especially knowing that resources are relatively scarce and limited, it is therefore pertinent that good information be made available for proper and accurate decision making, maximization of profitability and optimal utilization of scarce resource (Alzoubi, 2012).

\section{Significance of the Study}

The research study is of paramount to the researcher, commercial banks, other researchers and University. The main significance of this study is to generate information about the role of adverse selection in efficient and effective decision making in organizations which results into better performance. The information is anticipated to be vital to the management and staff at commercial banks and assist them to perform better in decision making and other companies. The study will act as a source of reference for other scholars who may undertake studies in the same field. University and other researchers will use this study in one way or other; act as a reference to other scholars who would want to venture into the same field, and thus contributing to the existence of literature. The study will enable the researcher to be acquainted with knowledge of how to deal with practical problem through research finding. The research will also enable the researcher to be awarded a master degree in Finance. This research will be used and consulted by other researcher to enhance their knowledge. Commercial banks and other companies will receive recommendations and suggestions concerning adverse selection and lending according to the research findings.

\section{Problem Statement}

Campbell (2007) indicates that Rwanda has the highest level of NPLs compared to the rest of the East African States, the study of Lin and Yu (2002) stated that the analysis of information in commercial banks in developing countries remains unsatisfactory and studies on this area are rare in the literature. This could be the main cause of low lending performance of commercial banks in Rwanda, where non-performing loan ratio (NPLs ratio) increased to $6.2 \%$ as at end December 2015 compared to 6.0\% recorded in December 2014. Although BNR has strengthened bank supervision and regulatory measures, NPLs still remain high and this influences the lending performance of commercial banks in Rwanda (National Bank of Rwanda, 2015).

The findings of Chiyachantana (2013) indicated larger firms; firms with high growth opportunity and superior performance are associated with level of information asymmetry. With respect to type of information, firms with superior operating performance, high growth opportunity are likely to disclose the investment and structural change as well as legal and miscellaneous information. While, the findings of Yosra and Sami (2013) indicated that listed companies with 
low growth opportunity and low corporate disclosure have low relative bid-ask spreads and high share turnover.

Conclusively, the evidence supports the notion that increasing corporate disclosure and transparency reduce the adverse selection between informed and uninformed traders. Furthermore, Yosra and Sami (2013) found that adverse selection is negatively related to financial commercial banks lending, while Adam, Anders and Fred (2013) revealed that information integration provides significant independent influences on performance of USA companies. However, from the empirical literature, the researcher recognized that different researchers from different countries did not have same understanding on adverse selection and performance of their case studies. This means that there a requirement of reducing adverse selection in order to allow the performance lending in commercial banks of Rwanda.

\section{Objectives of the Study}

The general objective of the study is to analyze the influence of adverse selection due to asymmetric information on commercial banks 'performance in Rwanda.

\section{Specific Objectives}

To analyze the influence of adverse selection asymmetric information on commercial banks' performance in Rwanda.

To determine the correlation between historical costs of adverse selection and commercial banks' performance in Rwanda.

To determine the link between adverse selection and lending performance of commercial banks.

\section{Research Hypotheses}

H01: There is no influence of adverse selection asymmetric information on commercial banks' performance in Rwanda.

H02: There is no correlation between historical costs of adverse selection and commercial banks' performance in Rwanda.

H03: There is no link between adverse selection and lending performance of commercial banks.

\section{Scope of the Study}

This subsection focuses on content scope, time scope and geographical scope. The researcher divided scope of the study into three parts in order to get accurate and update information concerning research objectives. Concerning content scope, this research focused on adverse selection and lending in commercial. The researcher chose this field, because even if information influences business performance cycle, there are few researches carried out on this field in 
Rwandan commercial banks. Concerning the time scope, this research considered a period scope of 10 years, such as 2006 - 2015, concerning geographical scope; this research was carried out on 10 strong markets leadership in banking sector in Rwanda located in Kigali City as indicated by Q1 2016.

\section{Theoretical Framework}

\section{Adverse Selection Theory}

When two (or more) individuals are about to agree on a trade, and one of them happens to have some information that the other(s) do not have, this situation is referred to as adverse selection(Akerlof \& Stiglitz, 1969). In 2001, the Nobel Prize in Economic Science was awarded to Akerlof, Spence and Stiglitz "for their analyses of markets with asymmetric information". Each of the three quoted papers investigates the implications of adverse selection on the product, labor and insurance markets respectively.

According to Nwauko and Ashinze (2015) Spence in 1973 refers to a similar mechanism when workers "sell" their labor to firms and have private information about their skills. The literature on adverse selection then investigates arrangements that allow segmentation of the market according to unobserved quality, sellers signal the quality of their products by offering productwarranties to customers, or workers signal their ability by getting academic degrees. It is important to emphasize that market segmentation does not primarily come from some information inherent to, say, warranties, but rather from menu of contracts offered to agents that leads to self-selection, revealing their private information.

\section{Historical Cost inform Ation Theory}

This study will be guided by historical cost theory, according to (John, 2008), cost control is concerned with past information and it requires consistency and comparability that is why it requires the accounting transactions to be recorded at their historical costs. This is called historical cost concept. Historical cost is the value of a resource given up or a liability incurred to acquire an asset/service at the time when the resource was given up or the liability incurred. In subsequent periods when there is appreciation is value, the value is not recognized as an increase in assets value except where allowed or required by accounting standards. The concept of historical cost is important because market values change so often that allowing reporting of assets and liabilities at current values would distort the whole fabric of accounting, impair comparability and makes accounting information unreliable(Alzoubi, 2012).

It is immediately clear that for financial statements to be meaningful, amounts of dissimilar items must be stated in similar units. Money becomes the obvious choice of "similar units". By converting different kinds of objects into monetary amounts, they can be dealt with arithmetically. Revenue that has associated expenses within a given accounting period should be reported in the same period. Matching the expense element to the revenue element makes it possible to assess accurately whether a profit or a loss occurred within that period (Chiyachantana, 2013). 


\section{Critical Review and Gap Identification}

Gheorghe (2007) carried out a research on the importance of information in making decisions. He found that the hidden costs management approach should be included in the short-term administration of the company. Alexandra (2006) carried out a research on the influence information on buyer-supplier negotiations in different power settings. The results founded indicate that the performance disadvantage of less powerful buyers was less pronounced when the buyer had detailed cost information and that this result can be explained by the buyer's negotiation behavior. The studies of Gheorghe (2007) and Alexandra (2006) contributed to academic indusstry, but they did not use both prmary and secondary data, so that they may come out with omparative analysis.Petur (2010) carried out the research on the classification and estimation of information. He conclude that having and maintaining costs of IT has never been as important, and will give companies a competitive edge and he said that knowing the accuracy of the estimate motivates businesses to improve the cost estimates until they have an acceptable granularity. The study of Petur (2010), only focus on cost information technology, but it did not indicate the benefits companies gain from cost information. The above critics indicate that, other studies did not show how adverse selection should affect commercial banks lending using both primary and secomdary sources of data. From the empirical literatiure, the researcher recognized that different researchers from different cuntries did not have same understanding on adverse selection and performance of their case studies. However, studies have been conducted in different sectors and there are few previous studies which have labored to investigate the concept of adverse selection and commercial banks' lending in Rwanda.

There is lack of academic knowledge on the subject of adverse selection asymmetric information and commercial banks' lending in Rwanda context which the current study seeks to bridge by availing data on the same subject using Commercial Banks as a case study. Moreover, the researcher also realized a gap where other researchers did not indicate how the performance of companies should be affected by adverse selection in developing countries like Rwanda. 
INTERNATIONAL JOURNAL OF ACADEMIC RESEARCH IN BUSINESS AND SOCIAL SCIENCES

Vol. 9, No. 11, November, 2019, E-ISSN: 2222-6990 @ 2019 HRMARS

\section{Conceptual framework}

Independent Variable

Adverse selection

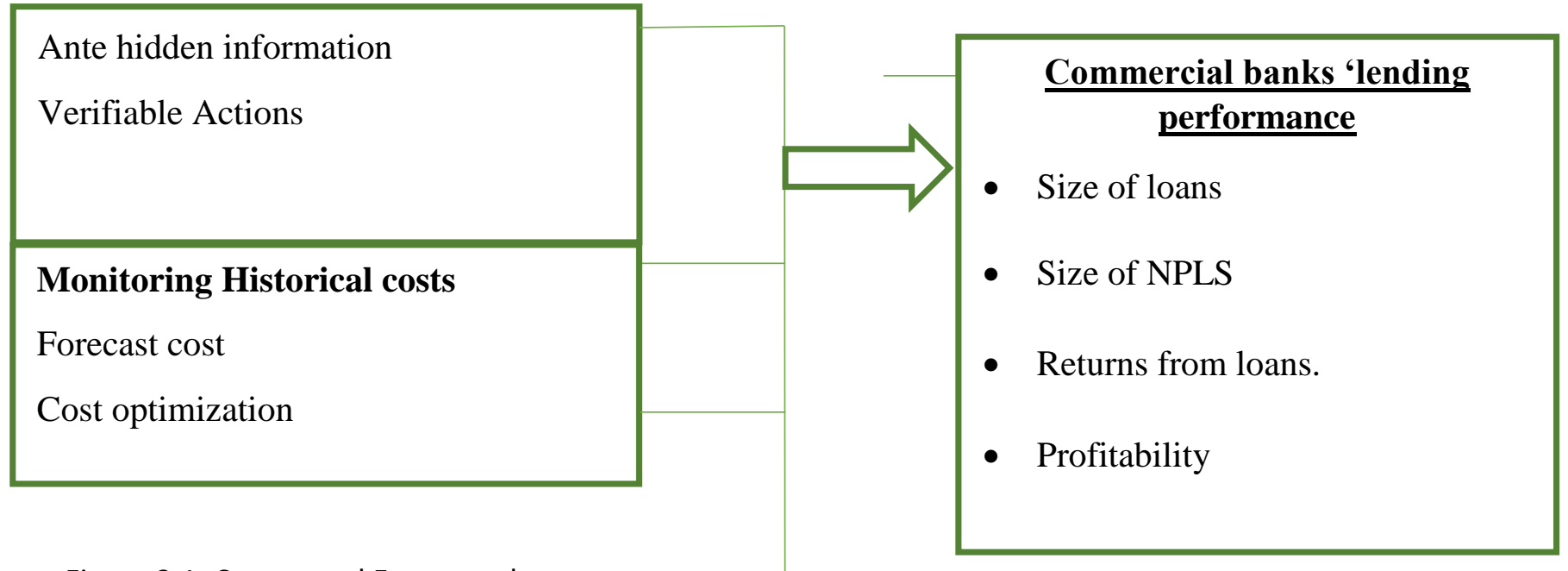

Figure 2.1: Conceptual Framework

Source: Researcher

\section{Intervening variables}

- Environmental factors 


\section{Research Methodology}

The study followed both correlation and comparative designs, and was both qualitative and quantitative. This is because the researcher quantitatively determined the relationship between variables and linear regression analysis is seen as the most appropriate for application in the study. Quantitative approach will also be used in order to achieve a higher degree of reliability. This study compared the lending performance of commercial banks in Rwanda in relation to the scope of the study. Population is the study object, which may be individuals, group, organizations human and events, or the conditions to which they are exposed. The population under study was comprised of board of directors, executives, top managers, middle managers and lower managers of 10 strong market leadership in banking sector in Rwanda as indicated by Q1 2016(BNR \& Researcher, 2016). The total target population will be 931 people as indicated in

Table 3.1.

Table 1: Sample frame

\begin{tabular}{lccc}
\hline Targeted Banks & Target Population & Proportion (\%) & Sample \\
\hline Bank of Kigali & 112 & 12.03 & 33 \\
Bank Populaire du Rwanda & 149 & 16.00 & 44 \\
I \&M Bank & 87 & 9.34 & 26 \\
Cogebanque & 79 & 8.49 & 24 \\
Ecobank & 102 & 10.96 & 30 \\
KCB & 104 & 11.17 & 31 \\
Equity & 63 & 6.77 & 19 \\
GT-Bank & 103 & 11.06 & 31 \\
Access Bank & 68 & 7.30 & 20 \\
CraneBank & 64 & 6.87 & 19 \\
Total & 931 & 100 & 278 \\
\hline
\end{tabular}

Source: (BNR \& Researcher, 2016)

In practice, the sample size to be used in the study was determined based on the expense of data collection, and the need to have sufficient statistical power. The level of precision or sampling error is $5 \%$ and $95 \%$ confidence level, total population $(N)$ is 931 , the sample size is selected using the Yamane formula $=\frac{\mathrm{N}}{1+\mathrm{N}(\mathrm{e}) 2}=\frac{931}{1+931 *(0.05)^{2}}=278$, and then, $\mathrm{n}=278$ employees. The researcher's intention was to ensure that the sample includes the elements that are directly relevant to the problem being investigated. The sample size is then proportionately distributed among the 10 commercial banks.

With stratified sampling, the researcher divided the population into separate groups, called strata. Then, a probability sample was drawn from each group, because stratified sampling has advantages over simple random sampling. Therefore, the researcher first classified population into strata. After grouping respondents, respondents were selected, such that everyone has the probability of being selected to be in the sample. The simple random sampling method gave each 
member an equal opportunity of being chosen. Hence, the study population was stratified into strata (groups) as indicated in the Table 3.1. From these strata, the researcher used systematic random sampling method in each strata to select 278 from 931 people as these enabled the researcher to give respondents equal opportunity to provide information related to research objectives.

The researcher used both primary and secondary data as practical means of obtaining information related to the research topic. The primary data was obtained using questionnaire and interview. Secondary data were sourced from annual reports of 10 selected commercial banks.

Questionnaire were used to collect primary data during the study, where each respondent was given blank questionnaire and fill it according to the research objectives. Interview guide was used to collect in-depth qualitative data; it was used for board of directors and executives.

Documentary review was also used because it helps the researchers to know and document the kind of additional data needed in the study. This is the second hand data that was specifically collected from respondents. For this study, the researcher used annual reports of selected commercial banks.

The researcher tried as much as possible to ensure that the findings of the research were properly analyzed and interpreted for accurate conclusions. The validity of this study was constructed by the use of sources of evidence during the data collection, the establishment of a chain of evidence which is based on the principle of allowing the external observer to follow the source of any evidence from initial research questions to the conclusions of the case study. Therefore, the researcher first carried out a pilot study in Bank of Kigali by testing questionnaires to 22 employees. And then after, the researcher tested questionnaire and calculated the Cronbach's Alpha coefficient, which was 0.893 and greater than 0.70 .

Before the data is entered into the computer for analysis and interpretation, the researcher will code and cross check responses. Both qualitative and quantitative techniques were employed to data manipulation. They included editing, coding and summarizing the data into frequencies and percentages using SPSS so as to aid the researcher to meaningfully describe the distribution of responses using a few indices. Qualitative data obtained were analyzed where opinions, ideas, beliefs, attitudes, statements or arguments were classified into themes, categorized and then discussed within the context of interpretation of research finding. The study variables were measured by designing questions on each variable, where each question (Close ended only) have different response options. Discriminating variables of ratios were analyzed using the Altman ' $Z$ ' score in order to arrive at the study findings. An integration of both qualitative and quantitative methods were relied upon in the course of this study. The data further were presented using equations, graphs, and tables, the data were also analyzed using regression analysis techniques to determine the relationship between the variables and the degree to which the independent variable explain the variation in the dependent variable. The data obtained were subjected to various computations and analysis. In the analysis percentages and ratios were done. The data were analyzed using Statistical Packaging for Social Sciences (SPSS) and E-Xcel .Altman Z-Score for private and non-manufacturing companies ; $Z=\beta_{1} X_{1}+\beta_{2} X_{2}+\beta_{3} X_{3}+\beta_{4} X_{4+\varepsilon_{t}}$, where $X_{1}$ 
$=$ Working capital/Total assets, $X_{2}=$ Retained Earnings/Total assets, $X_{3}=$ Earnings before interest and taxes/Total assets, $X_{4}=$ Market value equity/Book value of total debt, and $Z=$ Overall Index, and then $\beta_{1}, \beta_{2}, \beta_{3}$, and $\beta_{4}$ are respectively the coefficients of $\mathrm{X}_{1}, \mathrm{X}_{2}, \mathrm{X}_{3}$ and $\mathrm{X}_{4}$ were predicted using Altman Z-score calculator(Altman, 1993).

\section{Presentation of Findings}

This parts focuses on the analysis of research objectives, such as the influence of adverse selection asymmetric information to the performance of commercial banks in Rwanda and the correlation between cost forecast asymmetric information and performance of commercial banks in Rwanda.

4.2.2 The influence of adverse selection asymmetric information to the performance of bank Table 4.2: Views of respondents on information asymmetric before the contract is signed

\begin{tabular}{llllll} 
& & & & & Cumulative \\
Valid & Yes & 58 & 73.4 & 73.4 & 73.4 \\
& No & 21 & 26.6 & 26.6 & 100.0 \\
& & & & \\
& Total & 79 & 100.0 & 100.0 & \\
\hline
\end{tabular}

\section{Source: Field Data}

Table 4.15 indicate perception of respondents on cases where information is asymmetric even before the contract is signed in bank. Out of 79 respondents, $73.4 \%$ chose yes and $26.6 \%$ chose No.

Table 4.3: Adverse selection is primarily concerned with maximizing shareholder value

\begin{tabular}{llllll}
\hline & & & & Cumulative \\
\hline Valid & strongly agree & 30 & 38.0 & 38.0 & 38.0 \\
& Agree & 23 & 29.1 & 29.1 & 67.1 \\
& Undecided & 7 & 8.9 & 8.9 & 75.9 \\
& Disagree & 11 & 13.9 & 13.9 & 89.9 \\
strongly disagree & 8 & 10.1 & 10.1 & 100.0 \\
& Total & 79 & 100.0 & 100.0 & \\
\hline
\end{tabular}

Source: Field Data 
Table 4.16 present views of respondents on adverse selection asymmetric information as primarily concerned with maximizing shareholder value through long-term financial planning. Out of 79 respondents, $38.0 \%$ chose strongly agree, $29.1 \%$ chose agree, $8.9 \%$ chose undecided, $13.9 \%$ chose disagree and $10.1 \%$ chose strongly disagree. Shareholder value is a business term, sometimes phrased as shareholder value maximization or as the shareholder value model, which implies that the ultimate measure of a company's success is the extent to which it enriches shareholders.

Table 4.4: Adverse selection is primarily concerned with short-term financial planning

\begin{tabular}{llllll}
\hline & & & & Cumulative \\
Valid & strongly agree & 34 & 43.0 & 43.0 & 43.0 \\
& Agree & 21 & 26.6 & 26.6 & 69.6 \\
& Undecided & 11 & 13.9 & 13.9 & 83.5 \\
& Disagree & 6 & 7.6 & 7.6 & 91.1 \\
strongly disagree & 7 & 8.9 & 8.9 & 100.0 \\
Total & 79 & 100.0 & 100.0 & \\
\hline
\end{tabular}

\section{Source: Field Data}

Table 4.17 indicates views of respondents on adverse selection asymmetric information as primarily concerned with maximizing shareholder value through short-term financial planning. Out of 79 respondents, $43.0 \%$ chose strongly agree, $26.6 \%$ chose agree, $13.9 \%$ chose undecided, $7.6 \%$ chose disagree and chose strongly disagree. Companies develop short-term financial plans to meet budget and investment goals within one fiscal year. These plans have a higher degree of certainty compared to long-term plans. Short-term plans often are amended as financial and investment goals change. Businesses and individuals alike use short-term plans to manage shortterm cash deficits.

Table 4.5: Adverse selection concerned with the implementation of financial strategies

\begin{tabular}{llllll}
\hline & & & & Cumulative \\
& & Frequency & Percent & Valid Percent & Percent \\
\hline Valid & strongly agree & 13 & 16.5 & 16.5 & 16.5 \\
& Agree & 49 & 62.0 & 62.0 & 78.5 \\
& Undecided & 4 & 5.1 & 5.1 & 83.5 \\
Disagree & 6 & 7.6 & 7.6 & 91.1 \\
strongly disagree & 7 & 8.9 & 8.9 & 100.0 \\
Total & 79 & 100.0 & 100.0 & \\
\hline
\end{tabular}

\section{Source: Field Data}


Table 4.18 shows views of respondents on adverse selection asymmetric information concerned with the implementation of various financial strategies. Out of 79 respondents, $16.5 \%$ chose strongly agree, $62.0 \%$ chose agree, $5.1 \%$ chose undecided, $7.6 \%$ chose disagree and $8.9 \%$ chose strongly agree. Financial strategy implementation is the translation of chosen strategy into organizational action so as to achieve strategic goals and objectives. Strategy implementation is also defined as the manner in which an organization should develop, utilize, and amalgamate organizational structure, control systems, and culture to follow strategies that lead to competitive advantage and a better performance.

Table 4.6: Adverse selection is involved with capital investment decisions

\begin{tabular}{llllll}
\hline & & & & Cumulative \\
Valid & strongly agree & 31 & 39.2 & 39.2 & 39.2 \\
& Agree & 19 & 24.1 & 24.1 & 63.3 \\
& Undecided & 10 & 12.7 & 12.7 & 75.9 \\
& Disagree & 15 & 19.0 & 19.0 & 94.9 \\
strongly disagree & 4 & 5.1 & 5.1 & 100.0 \\
Total & 79 & 100.0 & 100.0 & \\
\hline
\end{tabular}

\section{Source: Field Data}

Table 4.19 indicate perception of respondents on adverse selection asymmetric information is involved with capital investment decisions in bank. Out of 79 respondents, $39.2 \%$ chose strongly agree, $24.1 \%$ chose agree, $12.7 \%$ chose undecided, $19.0 \%$ chose disagree and $5.1 \%$ chose strongly disagree. Capital investment analysis assesses long-term investments, which might include fixed assets like equipment, machinery or real estate. The goal of this process is to pinpoint the option that is most likely to be the most profitable for the business. Businesses may use techniques such as discounted cash flow analysis, risk-return analysis, risk-neutral valuation and utility theory in a capital investment analysis for better investment decision.

Table 4. 7: Adverse selection asymmetric information proposes investment to be made

\begin{tabular}{llllll}
\hline & & & & Cumulative \\
Valid & strongly agree & 22 & 27.8 & 27.8 & 27.8 \\
& Agree & 35 & 44.3 & 44.3 & 72.2 \\
& Undecided & 3 & 3.8 & 3.8 & 75.9 \\
Disagree & 7 & 8.9 & 8.9 & 84.8 \\
strongly disagree & 12 & 15.2 & 15.2 & 100.0 \\
Total & 79 & 100.0 & 100.0 & \\
\hline
\end{tabular}

Source: Field Data 
Table 4.20 indicate views of respondents on adverse selection asymmetric information proposes investment be made. Out of 79 respondents, $27.8 \%$ chose strongly agree, $44.3 \%$ chose agree, $3.8 \%$ chose undecided, $8.9 \%$ chose disagree and $15.2 \%$ chose strongly disagree. Adverse selection occurs when buyers have better information than sellers and so the highest cost consumer's end up buying a particular product and this should affect investment process.

Table 4.8: Adverse selection influences company equity or debt

\begin{tabular}{llllll}
\hline & & & & Cumulative \\
Valid & strongly agree & 24 & 30.4 & 30.4 & 30.4 \\
& Agree & 29 & 36.7 & 36.7 & 67.1 \\
& Undecided & 10 & 12.7 & 12.7 & 79.7 \\
& Disagree & 12 & 15.2 & 15.2 & 94.9 \\
strongly disagree & 4 & 5.1 & 5.1 & 100.0 \\
& Total & 79 & 100.0 & 100.0 & \\
\hline
\end{tabular}

\section{Source: Field Data}

Table 4.21 indicates that adverse selection asymmetric information affects company equity or debt, or combination of both. Out of 79 respondents, $30.4 \%$ chose strongly agree, $36.7 \%$ chose agree, $12.7 \%$ chose undecided, $15.2 \%$ chose disagree and $5.1 \%$ chose strongly disagree. In an accounting context, shareholders' equity represents the equity of a company as divided among shareholders of common or preferred stock. Debt is an amount owed for funds borrowed. The lender agrees to lend funds to the borrower upon a promise by the borrower to pay interest on the debt, usually with the interest to be paid at regular intervals.

Table 4.9: Adverse selection affects dividends payment and investment in the company

\begin{tabular}{llllll}
\hline & & & & Cumulative \\
& & Frequency & Percent & Valid Percent & Percent \\
\hline Valid & strongly agree & 30 & 38.0 & 38.0 & 38.0 \\
& Agree & 24 & 30.4 & 30.4 & 68.4 \\
& Undecided & 9 & 11.4 & 11.4 & 79.7 \\
Disagree & 10 & 12.7 & 12.7 & 92.4 \\
strongly disagree & 6 & 7.6 & 7.6 & 100.0 \\
Total & 79 & 100.0 & 100.0 & \\
\hline
\end{tabular}

\section{Source: Field Data}

Table 4.22 shows that adverse selection asymmetric information indicates if shareholders should be offered dividends on their investment in the company. Out of 79 respondents, $38.0 \%$ chose 
INTERNATIONAL JOURNAL OF ACADEMIC RESEARCH IN BUSINESS AND SOCIAL SCIENCES

Vol. 9, No. 11, November, 2019, E-ISSN: 2222-6990 @ 2019 HRMARS

strongly agree, $30.4 \%$ chose agree, $11.4 \%$ chose undecided, $12.7 \%$ chose disagree and $7.6 \%$ chose strongly disagree.A dividend is a payment made by a corporation to its shareholders, usually as a distribution of profits. When a corporation earns a profit or surplus, it can re-invest it in the business and pay a fraction of the profit as a dividend to shareholders.

Table 4.10: Adverse selection affects management of assets and liabilities

\begin{tabular}{llllll}
\hline & & & & Cumulative \\
& & Frequency & Percent & Valid Percent & Percent \\
\hline Valid & strongly agree & 34 & 43.0 & 43.0 & 43.0 \\
& Agree & 26 & 32.9 & 32.9 & 75.9 \\
& Undecided & 8 & 10.1 & 10.1 & 86.1 \\
Disagree & 5 & 6.3 & 6.3 & 92.4 \\
strongly disagree & 6 & 7.6 & 7.6 & 100.0 \\
Total & 79 & 100.0 & 100.0 & \\
\hline
\end{tabular}

Source: Field Data

Table 4.23 indicates that adverse selection asymmetric information facilitates management of assets and liabilities. Out of 79 respondents, $43.0 \%$ chose strongly agree, $32.9 \%$ chose agree, $10.1 \%$ chose undecided, $6.3 \%$ chose disagree and $7.6 \%$ chose strongly disagree. Asset management is a systematic process of deploying, operating, maintaining, upgrading, and disposing of assets cost-effectively. The term is most commonly used in the financial market to describe companies that manage investments on behalf of others

Table 4.11: Adverse selection affects market value of equity

\begin{tabular}{llllll}
\hline & & & & Cumulative \\
& & Frequency & Percent & Valid Percent & Percent \\
\hline Valid & strongly agree & 29 & 36.7 & 36.7 & 36.7 \\
& Agree & 27 & 34.2 & 34.2 & 70.9 \\
& Undecided & 7 & 8.9 & 8.9 & 79.7 \\
& Disagree & 10 & 12.7 & 12.7 & 92.4 \\
strongly disagree & 6 & 7.6 & 7.6 & 100.0 \\
& 79 & 100.0 & 100.0 & \\
\hline
\end{tabular}

\section{Source: Field Data}

Table 4.24 presents that adverse selection asymmetric information facilitates market value of equity. Out of 79 respondents, $36.7 \%$ chose strongly agree, $34.2 \%$ chose agree, $8.9 \%$ chose undecided, $12.7 \%$ chose disagree and $7.6 \%$ chose strongly disagree. This implies that asymmetric information affects the price an asset would fetch in the marketplace. Market value is also 
commonly used to refer to the market capitalization of a publicly-traded company, and is obtained by multiplying the number of its outstanding shares by the current share price. However, the greatest difficulty in determining market value lies in estimating the value of illiquid assets like real estate and businesses, which may necessitate the use of real estate appraisers and business valuation experts respectively. Hence, asymmetric information affects the highest estimated price that a buyer would pay and a seller would accept for an item in an open and competitive market.

Table 4.12: Adverse selection influences book value of equity

\begin{tabular}{llllll}
\hline & & & & Cumulative \\
& & Frequency & Percent & Valid Percent & Percent \\
\hline Valid & strongly agree & 33 & 41.8 & 41.8 & 41.8 \\
& Agree & 23 & 29.1 & 29.1 & 70.9 \\
& Undecided & 5 & 6.3 & 6.3 & 77.2 \\
& Disagree & 9 & 11.4 & 11.4 & 88.6 \\
strongly agree & 9 & 11.4 & 11.4 & 100.0 \\
\hline
\end{tabular}

\section{Source: Field Data}

Table 4.25 indicate adverse selection asymmetric information facilitates book value of equity. Out of 79 respondents, $41.8 \%$ chose strongly agree, $29.1 \%$ chose agree, $6.3 \%$ chose undecided, $11.4 \%$ chose disagree and $11.4 \%$ chose strongly disagree. For assets, the value is based on the original cost of the asset less any depreciation, amortization or impairment costs made against the asset. Traditionally, a company's book value is its total assets minus intangible assets and liabilities

Table 4.27: Cost forecast information predicts non-manufacturing costs to be used

\begin{tabular}{llllll}
\hline & & & & Cumulative \\
& & Frequency & Percent & Valid Percent & Percent \\
\hline Valid & strongly agree & 30 & 38.0 & 38.0 & 38.0 \\
& Agree & 27 & 34.2 & 34.2 & 72.2 \\
& Undecided & 6 & 7.6 & 7.6 & 79.7 \\
Disagree & 9 & 11.4 & 11.4 & 91.1 \\
strongly disagree & 7 & 8.9 & 8.9 & 100.0 \\
Total & 79 & 100.0 & 100.0 & \\
\hline
\end{tabular}

Source: Field Data 
INTERNATIONAL JOURNAL OF ACADEMIC RESEARCH IN BUSINESS AND SOCIAL SCIENCES

Vol. 9, No. 11, November, 2019, E-ISSN: 2222-6990 ㄷ 2019 HRMARS

Table 4.31 present views of respondents on cost forecast information predicts nonmanufacturing costs to be used. Out of 79 respondents, $38.0 \%$ chose strongly agree, $34.2 \%$ chose agree, $7.6 \%$ chose undecided, $11.4 \%$ chose disagree, $8.9 \%$ chose strongly disagree. Nonmanufacturing costs are reported on a company's income statement as expenses in the accounting period in which they are incurred. Nonmanufacturing costs are the business expenses that are outside of a company's manufacturing operations. These are often referred to as the selling, general and administrative expenses plus the company's interest expense.

Table 13: The correlation between cost forecast asymmetric information and performance of bank

\begin{tabular}{llcr} 
& Cost Forecast & Performance \\
\hline Cost Forecast & Pearson Correlation & 1 & $.971^{* *}$
\end{tabular}

Sig. (2-tailed)

.000

$\mathrm{N}$

79

79

Performance

Pearson Correlation

$.971^{* *}$

Sig. (2-tailed)

.000

$\mathrm{N}$

**. Correlation is significant at the 0.01 level (2-tailed).

Table 3 indicates correlation between cost forecast asymmetric information and performance of bank. This research used SPSS programm and found that the coefficient $r$ equal to 0.971 . The variation of Pearson coefficient correlation is between -1 and 1 . According to Pearson, the correlation of $0.971(97.1 \%)$ is categorized as positive correlation and this leads to confirm that there is significant correlation between cost forecast asymmetric information and performance of bank. Therefore, this research found that there is a positive correlation between cost forecast asymmetric information and performance of bank. 


\begin{tabular}{|c|c|c|c|}
\hline & & $\begin{array}{l}\text { Asymmetric } \\
\text { Information }\end{array}$ & Performance \\
\hline \multirow[t]{3}{*}{ Asymmetric Information } & Pearson Correlation & 1 & $.982^{* *}$ \\
\hline & Sig. (2-tailed) & & .000 \\
\hline & $N$ & 79 & 79 \\
\hline \multirow[t]{3}{*}{ Performance } & Pearson Correlation & $.982^{* *}$ & 1 \\
\hline & Sig. (2-tailed) & .000 & \\
\hline & $\mathrm{N}$ & 79 & 79 \\
\hline
\end{tabular}

**. Correlation is significant at the 0.01 level (2-tailed).

Table 4 indicates relationship between information asymmetry and performance of bank. This research used SPSS programm and found that the coefficient $r$ equals to $\mathbf{0 . 9 8 2}$. The variation of Pearson coefficient correlation is between -1 and 1 . According to Pearson, the correlation of $0.982(98.2 \%)$ is categorized as positive correlation and this leads to confirm that there is significant relationship between information asymmetry and performance of bank. Therefore, this research found that there is a positive relationship between information asymmetry and performance of bank.

The analysis of Performance of Commercial banks Using Altman Z-score

This section indicates the analysis of performance of selected commercial banks, such bank of Kigali and BPR, as indicated into tables. The test of performance of selected commercial banks was testing using Altman Z-Score where; $Z=\beta_{1} X_{1}+\beta_{2} X_{2}+\beta_{3} X_{3}+\beta_{4} X_{4+\beta_{5} X_{5+\cdots . . . . .}}, \mathrm{X}_{1}$ $=$ Working capital/Total assets, $X_{2}=$ Retained Earnings/Total assets, $X_{3}=$ Earnings before interest and taxes/Total assets, $X_{4}=$ Market value equity/Book value of total debt, $X_{5}$. $=$ Sales to Total Assets and $Z=$ Overall Index, and then $\beta_{1}, \beta_{2}, \beta_{3}, \beta_{4}$ and $\beta_{5}$ are respectively the coefficients of $X_{1}, X_{2}, X_{3}, X_{4}$ and $X_{5}$ will be predicted using Altman Z-score calculator (Altman, 1993). According to Altman (2000), for commercial banks $Z=1.2 X_{1}+1.4 X 2+3.3 X 3+0.6 X 4+1.0 X 5$. Hence, $\beta_{1}=1.2$, $\beta_{2}=1.4, \beta_{3}=3.3 \beta_{4}=0.6$ and $\beta_{5}=1.0$. 
INTERNATIONAL JOURNAL OF ACADEMIC RESEARCH IN BUSINESS AND SOCIAL SCIENCES

Vol. 9, No. 11, November, 2019, E-ISSN: 2222-6990 ㄷ 2019 HRMARS

Table 15: Analysis of bank of Kigali financial performance in 2014

\begin{tabular}{|c|c|c|c|c|}
\hline Altman Factors & $\begin{array}{l}\text { Value of } \\
\text { factors "000 } \\
\text { Frws" }\end{array}$ & Five ratio & $\begin{array}{l}\text { Value of } \\
\text { ratios }\end{array}$ & Z Score value \\
\hline Working Capital(WC) & $33,226,114$ & WC/TA & 0.69 & \\
\hline Retained Earnings (RE) & $20,359,836$ & RE/TA & 0.42 & \\
\hline EBIT & $22,758,705$ & EBIT/TA & 0.47 & $Z=5.4$ \\
\hline $\begin{array}{l}\text { Sales } \\
\text { Market Value Equity } \\
\text { (MVE) }\end{array}$ & $51,909,827$ & Sales/ TA & 1.08 & \\
\hline $\begin{array}{l}\text { Total Asset (TA) } \\
\text { Book value of total debt } \\
\text { (BVD) }\end{array}$ & $\begin{array}{c}48,260,796.4 \\
39,929,967\end{array}$ & & & \\
\hline
\end{tabular}

Source: Bank of Kigali, 2014

Table 5 presents test for bank of Kigali performance in 2014, where $Z=1.2 * 0.69+1.4 * 0.42+$ $3.3 * 0.47+0.6 * 2.2+1.0 * 0.108=5.4$. This value indicates that, there was very healthy performance of bank of Kigali in 2014.

Table 16: Analysis of bank of Kigali financial performance in 2013

\begin{tabular}{lccll}
\hline Altman Factors & $\begin{array}{l}\text { Value of } \\
\text { factors }\end{array}$ & Five ratios & $\begin{array}{l}\text { Value of } \\
\text { ratios }\end{array}$ & $\begin{array}{l}\text { Z Score } \\
\text { value }\end{array}$ \\
\hline Working Capital & $74,126,523$ & WC/TA $=$ & 1.755055171 & \\
Retained Earnings & $8,947,377$ & RE/TA $=$ & 0.211842396 & \\
EBIT & $18,756,236$ & EBIT/TA $=$ & 0.444081654 & Z=6.18 \\
Sales & $45,210,752$ & Sales/TA= & 1.070431485 & \\
$\begin{array}{l}\text { Market value equity } \\
\text { Total asset }\end{array}$ & $70,763,684$ & MVE/BVD $=$ & 2.069687331 & \\
$\begin{array}{l}\text { Book value of total } \\
\text { debt }\end{array}$ & $42,236,007$ & & & \\
\hline
\end{tabular}

Source: Bank of Kigali, 2013

Table 6 presents test for bank of Kigali performance in $2013, \quad Z=1.2 * 1.755+1.4 * 0.211+$ $3.3 * 0.444+0.6 * 2.070+1.0 * 0.107=6.18$. This value indicates that, there was very healthy performance of bank of Kigali in 2013. 
INTERNATIONAL JOURNAL OF ACADEMIC RESEARCH IN BUSINESS AND SOCIAL SCIENCES

Vol. 9, No. 11, November, 2019, E-ISSN: 2222-6990 ㄷ 2019 HRMARS

Table 17: Analysis of bank of Kigali financial performance in 2012

\begin{tabular}{lcccc}
\hline Altman Factors & Value of factors & Five ratios & Value of ratios & Z Score value \\
\hline Working Capital & $-16,822,722$ & WC/TA & -0.521159341 & \\
Retained Earnings & $6,893,076$ & RE/TA & 0.213543976 & \\
EBIT & $14,466,909$ & EBIT/TA & 0.448177457 & Z $=2.78$ \\
Sales & $32,069,789$ & Sales/TA & 0.993505695 & \\
Market value equity & $63,107,293$ & MVE/BVD & 10.61522734 & \\
Total asset & $32,279,421$ & & & \\
Book value of total debt & $59,449,780$ & & & \\
\hline
\end{tabular}

Source: Bank of Kigali, 2012

Table 7 presents test for bank of Kigali performance in 2012, $\quad Z=1.2 *(-0.52)+1.4 * 0.21+$ $3.3 * 0.45+0.6 * 10.615+1.0 * 0.99=2.78$. This value indicates that, there was healthy performance of bank of Kigali in 2013. In comparison of results of 2014, 2013 and 2012, this study revealed that bank of Kigali has a positive financial performance.

Table 18: Analysis of BPR financial performance in 2014

\begin{tabular}{lcccc}
\hline & $\begin{array}{l}\text { Value of } \\
\text { factors “000 }\end{array}$ & & & \\
Altman Factors & Frws” & Five ratios & Value of ratios & Z Score value \\
\hline Working Capital & $-9,854,894$ & WC/TA & -0.020420082 & \\
Retained Earnings & $-2,222,237$ & RE/TA & -0.004604642 & \\
EBIT & $1,467,694$ & EBIT/TA & 0.003041172 & 2.73 \\
Market value equity & $15,880,898$ & MVE/BVD & 4.523688774 & \\
Sales & $19,544,228$ & Sales/TA & 0.04049711 & \\
Total asset & $482,607,964$ & & & \\
Book value of total debt & $3,510,608$ & & & \\
\hline
\end{tabular}

Source: BPR, 2014

Table 8 presents test for BPR performance in 2014, $Z=1.2 *-0.020+1.4 *-0.005+3.3 * 0.003+$ $0.6 * 4.523+1.0 * 0.0 .04=2.73$. This value indicates that, there was healthy performance of BPR in 2014. 
INTERNATIONAL JOURNAL OF ACADEMIC RESEARCH IN BUSINESS AND SOCIAL SCIENCES Vol. 9, No. 11, November, 2019, E-ISSN: 2222-6990 ㄷ 2019 HRMARS

Table 19: Analysis of BPR financial performance in 2013

\begin{tabular}{lcccc}
\hline & $\begin{array}{l}\text { Value of } \\
\text { factors “000 }\end{array}$ & & & \\
Altman Factors & Frws” & Five ratios & Value of ratios & Z Score value \\
\hline Working Capital & $11,639,744$ & WC/TA & 0.027558817 & \\
Retained Earnings & $-3,317,644$ & RE/TA & -0.007855013 & \\
EBIT & $-6,839,612$ & EBIT/TA & -0.016193794 & 1.17 \\
Market value equity & $13,781,375$ & MVE/BVD & 1.9262414 & \\
Sales & $19,989,207$ & Sales/TA & 0.047327407 & \\
Total asset & $422,360,073$ & & & \\
Book value of total debt & $7,154,542$ & & & \\
\hline
\end{tabular}

Source: BPR, 2013

Table 9 presents analysis of BPR financial performance in $2013, Z=1.2 * 0.028+1.4 *-0.008+3.3 *$ $0.016+0.6 * 1.93+1.0 * 0.047=1.17$. This value indicates that, there was weak performance of BPR in 2013.

Table 20: Analysis of BPR financial performance in 2012 "000 Frws"

\begin{tabular}{lcccc}
\hline Altman Factors & $\begin{array}{l}\text { Value of } \\
\text { factors }\end{array}$ & Five ratios & Value of ratios & Z Score value \\
\hline Working Capital & $-10,163,457$ & WC/TA & -0.031485871 & \\
Retained Earnings & $-82,351$ & RE/TA & -0.000255119 & \\
EBIT & $-229,558$ & EBIT/TA & -0.000711159 & 1.48 \\
Market value equity & $18,947,887$ & MVE/BVD & 2.418211868 & \\
Sales & $22,574,358$ & Sales/TA & 0.069934209 & \\
$\begin{array}{l}\text { Total asset } \\
\text { Book value of total }\end{array}$ & $322,794,214$ & & & \\
debt & $7,835,495$ & & & \\
\hline
\end{tabular}

Source: BPR, 2012

Table 10 presents analysis of BPR financial performance in $2012, \mathrm{Z}=1.2 * 0.028+1.4 *-0.008+$ $3.3 *-0.016+0.6 * 1.93+1.0 * 0.047=1.48$. This value indicates that, there was weak performance of BPR in 2012.This results also confirmed by the annual reports of BPR in 2012. 


\section{Conclusions}

This research concluded that bank focuses on the analysis of adverse selection.

This research concluded that bank makes related information comparable between different items in order to minimize adverse selection in the organization.

This study also concluded that the performance disadvantage of less powerful buyers was less pronounced in bank when the buyer had detailed cost information and that this result can be explained by the buyer's negotiation behavior. It is also concluded that decision to introduce to financial management information needs to be accompanied by strong commitment, sufficient manpower and financial resources, widespread internal support, and an agenda for effective communication.

\section{Recommendations}

Even if this study found that bank used different elements in terms of adverse selection, it focused only on its performance in consecutive period rather than performance with other companies in the same industry. Hence, bank should use comparative analysis using comparison with other companies in the commercial banks sectors.

Basing on the findings related to the problems as well as the theoretical aspects presented in the literature review this research recommends commercial banks of Rwanda to speed up the campaign to focus on the management of adverse selection as among the best tool to the profitability of commercial banks. This research also recommended that, the employees are considered as a very important requirement to the operation and the procedures in every organization, so bank have to improve the skills of the employees working in the management of adverse selection.

The researcher recommended commercial banks that, management of bank must have interdependent relationships that management needs to perform its activities. Since commercial banks contribute to the highest cost among the related elements in cost of raw material, the improvement of profitability efficiency could change the overall profitability.

This research focused on adverse selection and performance of commercial banks

\section{Acknowledgement}

My sincere appreciation goes to my husband Théogene RUSANGANWA, for shaping and right direction given to the researcher. To my supervisors for the work they have done especially in guidance and supervision which helped the researcher to improve professional skills and ethics in research. I acknowledge the administration of Jomo Kenyatta University for giving all required legal documents which helped the researcher during the research. I would also acknowledge the lecturers who taught me in the Doctorate program for knowledge and skills I acquired from them, fellow students who helped me in different ways. 


\section{References}

1. Adam, S. M., Anders, N., \& Fred, A. J. (2013). Assessing the interaction effect of cost control systems and information technology integration on plant financial performance. Journal of The British Accounting, Vol.30(4), PP. 1-14.

2. Akerlof, G. A., \& Stiglitz, J. E. (1969). Capital, wages and structural unemployment. Economic Journal, 79(7), 269-281.

3. Alexandra, F. (2006). The effect of cost information on buyer-supplier negotiations in different power settings. Naamsestraat: Katholieke Universiteit Leuven.

4. Alzoubi, A. (2012). The Effectiveness of the Accounting Information System:Under the Enterprise Resources Planning (ERP). Research Journal of Finance and Accounting, Vol.2 (11), pp. $10-18$.

5. Augustine, M., Maureen, K. M., \& Jian, Z. (2014). Impact of Accounting Information Systems on Profitability of Small Scale Businesses: A Case of Kampala City in Uganda. International Journal of Academic Research in Management (IJARM), Vol.3(4), PP.185192.

6. Aysan, M. (2006). A history of the accounting profession in Turkey. Journal of Financial Analyze Special Issue, PP.13-16.

7. Chiyachantana, C. (2013). The effect of information disclosure on information asymmetry. Journal of Investment Management and Financial Innovations, 4(1), 225 - 234.

8. Elena, U. G., Raquel,Pérez, E., \& Clara, M. (2011). The impact of Accounting Information Systems on performance measures:empirical evidence in Spanish SMEs. Journal of Digital Accounting Research, Vol.11, pp. 25 - 43.

9. Frank, V. K. (2000). The Labor Movement in Democratic Chile, 1990-2000. New York: Helen Kellog Institute of International Studies.

10. Gale, A. (2004). Competition and financial stability. Journal of Money Credit and Banking, Vol.36, pp. 453-481.

11. Gautam, A., \& Riitta, K. (2001). Technological Acquisitions And The Innovation Performance Of Acquiring Firms: A Longitudinal Study. Strategic Management Journal, Vol.22(2), PP.197-220.

12. Gheorghe, G. (2007). The Importance of the Cost Information in Making Decisions. Bucharest: Christian University "Dimitrie Cantemir.

13. Government of Rwanda. (2013). Economic Development and Poverty Reduction Strategy (EDPRS) 2013 - 2018. Kigali: Government of Rwanda.

14. Gus, D., Kothari, S. P. \& Rodrigo, S. V. (2009). The Benefits of Financial Statement Comparability. Toronto, Canada: University of Toronto.

15. Innes, J., \& Mitchell, F. (2000). A Review of Activity-Based Cost Practice in Handbook of Management Accounting Practice. London, United Kingdom: Butterworth- Heinemann Ltd.

16. Jack, D., \& Pokar, K. (2005). Introducing Financial Management Information Systems in Developing Countries. International Monetary Fund: International Monetary Fund. 
17. Javad, A., Hamed, A., \& Elham, H. (2012). A Comprehensive Review on Capital Structure Theories. Vol.2(1), PP.35 - 45.

18. John, W. D. (2008). Accounting Cost Concepts. Stanford: John W. Day.

19. Lin, Z. J., \& Yu, Z. (2002). Responsibility cost control system in China: a case of management accounting application. Journal of Management Accounting Research, Vol.13(4), PP.447-467.

20. Mehran, A., \& Izah, M. (n.d.). Performance Analysis of Companies in Pakistan. Journal of Business Management Dynamics, 1(7), 12-21.

21. Mohammad, K. (2013, January). Essays on -related management accounting Andreas Myrelid. -related management accounting journal, vol. 4, pp. 32 - 45.

22. Nwauko, A., \& Ashinze, A. (2015). An empirical analysis of the effects of asymmetric information in the Kano markets for used phones. AshEse Journal of Economics, Vol.1(3), 030 - 056.

23. Olweny, T., \& Shipo, T. M. (2011). Effects of Banking Sectorial Factors on the Profitability of Commercial Banks in Kenya. Economics and Finance Review, Vol.1(5), 1-30.

24. Paul, K. (2001). Information asymmetry,Corporate disclosur and Capital markets. Journal of Accounting and Economics, Vol.31, pp.405-440.

25. Petur, K. (2010). The classification and estimation of cost in information technology. reykijavic: university of iceland.

26. Praveen, K. (1990). Information asymmetries: source of competitive advanatage for diversified service firms. Strategic Management journal, PP.513-519.

27. Roger, R. (2004). Costing of Information Services. University of Reading.

28. Soudani, S. N. (2012). The Usefulness of an Accounting Information System for Effective Organizational Performance. International Journal of Economics and Finance, Vol.4(5), PP.136 - 145.

29. Varian. (2000). Microeconomia: Rio de Janeiro: W. W. Norton \& Company.

30. Vojtech, C. M. (2013). The Relationship Between Information Asymmetry and Dividend Policy. Washington, D.C.: Finance and Economics Discussion Series Divisions of Research \& Statistics and Monetary Affairs Federal Reserve Board. 